\title{
Hypoxia in prostate cancer
}

\author{
Peter Vaupel \\ Department of Radiation Oncology and Radiotherapy, Tumor Pathophysiology Group, University Medical Center, Mainz 55131, \\ Germany.
}

Correspondence to: Prof. Dr. med. Peter Vaupel, Department of Radiation Oncology and Radiotherapy, Tumor Pathophysiology Group, University Medical Center, Langenbeckstrasse 1, Mainz 55131, Germany. E-mail: vaupel@uni-mainz.de

How to cite this article: Vaupel P. Hypoxia in prostate cancer. J Cancer Metastasis Treat 2018;4:20. http://dx.doi.org/10.20517/2394-4722.2018.30

Received: 30 Mar 2018 Accepted: 20 Apr 2018 Published: 7 May 2018

Science Editor: Lucio Miele Copy Editor: Jun-Yao Li Production Editor: Cai-Hong Wang

Dear Editor,

I have read with great interest the review "Current challenges and opportunities in treating hypoxic prostate tumors" by McKenna et al. ${ }^{[1]}$. In this review, the authors present, as a key information in Table 1 of their article, values of oxygen partial pressures $\left(\mathrm{pO}_{2}\right)$ in human tumors and the respective normal tissues, published earlier by our group ${ }^{[2,3]}$ and "adapted" by McKeown ${ }^{[4]}$ later.

In their article, McKenna et al. ${ }^{[1]}$ have reviewed current knowledge about the impact of the "hallmark feature" hypoxia on pathways promoting cancer growth, malignant progression, therapeutic resistance and tumor immune escape ${ }^{[5-7]}$. Certainly, this information is of utmost interest to experimental and clinical oncologists. However, since this review contains some misleading/inappropriate oxygenation data, some additional information that may be of interest for the distinguished readership of this highly reputed journal, may serve for clarification.

In Table 1 of their review, McKenna et al. ${ }^{[1]}$ present oxygen partial pressure $\left(\mathrm{pO}_{2}\right)$ values together with oxygen concentration $\left(\mathrm{CO}_{2}\right)$ data. When reviewing the biological role of hypoxia in malignant tumors, authors lacking an expertise in respiratory physiology often convert - without any need - the in vivo $\mathrm{pO}_{2}$ values, originally measured in tumors (and in normal tissues) using $\mathrm{pO}_{2}$ histography ${ }^{[2]}$, into $\mathrm{O}_{2}$ concentrations using either Dalton's law (only valid for gas mixtures within the airways) or Henry's law for gases dissolved in solutions, which cannot describe the relationship between partial pressures and concentrations of gases in heterogeneous media (e.g., tissues with lipid-rich membranes, the cytosol and the extracellular space, the latter with a high content of free water in cancers). Therefore, it is strongly suggested to avoid any conversion of measured $\mathrm{pO}_{2}$ values into $\mathrm{CO}_{2}$ data since the $\mathrm{O}_{2}$ solubility coefficient is: (1) highly dependent on the tissue water content; and (2) usually not known for heterogeneous cancer tissues in patients. In this context, it has

\footnotetext{
(a) (1)

(C) The Author(s) 2018. Open Access This article is licensed under a Creative Commons Attribution 4.0 International License (https://creativecommons.org/licenses/by/4.0/), which permits unrestricted use, sharing, adaptation, distribution and reproduction in any medium or format, for any purpose, even commercially, as long as you give appropriate credit to the original author(s) and the source, provide a link to the Creative Commons license, and indicate if changes were made.
} 
to be mentioned that authors not familiar with respiratory physiology often use "local $\mathrm{O}_{2}$ concentrations" by mistake, although $\mathrm{pO}_{2}$ values have been measured in the original studies ${ }^{[2,3]}$ (for typical examples see Table 1 in the review by McKenna et al. $\left.{ }^{[1]}\right)$.

Considering Henry's law ( $\mathrm{cO}_{2}=\alpha \times \mathrm{pO}_{2} ; \alpha$ : oxygen solubility coefficient), McKenna et al. ${ }^{[1]}$ have communicated questionable oxygenation data grounded on wrong/doubtful $\mathrm{O}_{2}$ solubility values for malignant and normal tissues, which originally have been communicated for blood plasma, i.e., irrelevant data when heterogeneous tissues such as prostate cancer are considered ${ }^{[8]}$.

Oxygen solubility coefficients for heterogeneous tissues (e.g., for experimental tumors ${ }^{[9]}$ ) are significantly lower than those for blood or blood plasma ${ }^{[10]}$. Due to this misconception, the $\mathrm{O}_{2}$ concentration data of Table 1 in the review by McKenna et al. ${ }^{[1]}$ are misleading/not correct and should, therefore, be removed from the table. There is no need to present concentration data in this comprehensive review.

\section{DECLARATIONS}

\section{Authors' contributions}

Vaupel P contributed solely to the paper.

\section{Financial support and sponsorship}

None.

\section{Conflicts of interest}

There are no conflicts of interest.

\section{Patient consent}

Not applicable.

\section{Ethics approval}

Not applicable.

\section{Copyright}

(c) The Author 2018.

\section{REFERENCES}

1. McKenna DJ, Errington R, Pors K. Current challenges and opportunities in treating hypoxic prostate tumors. J Cancer Metastasis Treat 2018;4:11.

2. Vaupel P, Höckel M, Mayer A. Detection and characterization of tumor hypoxia using pO2 histography. Antioxid Redox Signal 2007;9:1221-35.

3. Vaupel P, Kelleher DK. Blood flow and oxygenation status of prostate cancers. Adv Exp Med Biol 2013;765:299-305.

4. McKeown SR. Defining normoxia, physoxia and hypoxia in tumours-implications for treatment response. Br J Radiol 2014;87:20130676.

5. Vaupel P, Mayer A. Hypoxia in cancer: significance and impact on clinical outcome. Cancer Metastasis Rev 2007;26:225-39.

6. Vaupel P, Mayer A, Höckel M. Tumor hypoxia and malignant progression. Methods Enzymol 2004;381:335-54.

7. Vaupel P, Multhoff G. A metabolic immune checkpoint: adenosine in tumor microenvironment. Front Immunol 2016;7:332.

8. Vaupel P, Mayer A. Tumor oxygenation status: facts and fallacies. Adv Exp Med Biol 2017;977:91-9.

9. Grote J, Süsskind R, Vaupel P. Oxygen diffusivity in tumor tissue (DS-carcinosarcoma) under temperature conditions within the range of 20-40 C. Pflügers Arch 1977;372:37-42.

10. Thews G, Vaupel P. Autonomic Functions in Human Physiology. Berlin, Heidelberg, New York, Tokyo: Springer; 1985. 